\title{
Terrorist Threats: Measuring the Terms and Approaches
}

\author{
Kartini Aboo Talib@ $@$ Khalid $^{1}$,Sakina Shaik Ahmad Yusoff ${ }^{2}$, Rahmah Ismail ${ }^{2}$, Shamsudin Suhor ${ }^{2}$, Azimon Abdul \\ Aziz $^{3} \&$ Muhammad Rizal Razman ${ }^{4}$ \\ ${ }^{1}$ Institute of Ethnic Studies, National University of Malaysia, Bangi, Malaysia \\ ${ }^{2}$ Faculty of Law, National University of Malaysia, Bangi, Malaysia \\ ${ }^{3}$ Faculty of Economics and Management, National University of Malaysia, Bangi, Malaysia \\ ${ }^{4}$ Institute for Environment and Development, National University of Malaysia, Bangi, Malaysia \\ Correspondence: Kartini Aboo Talib @ Khalid, Institute of Ethnic Studies, National University of Malaysia, \\ 43600 Bangi, Selangor, Malaysia. Tel: 60-19-289-6020. E-mail: k_khalid@ukm.my
}

Received: August 1, 2012 Accepted: August 30, 2012 Online Published: November 30, 2012

doi:10.5539/ass.v8n15p288 URL: http://dx.doi.org/10.5539/ass.v8n15p288

This research is funded by the Arus Perdana Research Grant, UKM-AP-CMNB-02-201. Authors acknowledged Dr Karen Vautour in Salem, Massachusetts for her editing and proof reading contributions to this article.

\begin{abstract}
This article discusses terrorist networks that operate locally with diverse interests. A comparative study between Malaysia and Indonesia is discussed in this article, because these organizations share significant features that raise questions on their very existence. Ironically differing perspectives on threat contribute to differing actions by both countries. Although these fundamental Islamic groups are assumed to be standard and organized, their organizations turn out to be loose and cannot be sufficiently accepted as an organization. Factors such as family and kinship, unclear funding, and members' lack recognition may annul the meaning of the organization. Competing terms on terrorism and Jihad are explained in this article. Both comprise difficult conceptual frameworks. Understanding their modus operandi and examining the states' actions and mechanisms to curb any possible terrorist threat in the region are also central to this discussion. Both Malaysia and Indonesia show commitments to secure their borders and heighten state security, including assessing the group mobility and security enforcement.
\end{abstract}

Keywords: terrorist, organization, network, security, mechanism

\section{Introduction}

Southeast Asia has long been threatened by fundamentalist-oriented groups particularly in Southern Thailand, the Philippines, and Acheh. Bilveer Singh (2007) posits that these armed Islamic groups who declared war against central governments are aiming to gain political autonomy through secession. This armed struggle motivates the United States to make a secondary front campaign on terrorism in this region. Although Acharya \& Acharya (2007) criticize that the USA's global war on terrorism is viewed by many Muslim majority countries as a global war on Islam due to Washington's one-size-fits-all counter-terrorism initiatives, efforts from the governments in Southeast Asia to curb and to prevent terrorism are serious after the September 11, 2001 attacks in the USA. That tragedy urged the governments in Southeast Asia, particularly Malaysia, Singapore and Indonesia, to launch their own war on terrorism.

Southeast Asia is prone to Islamic movements for several reasons. First, there is a sizeable population of Muslims in this region, more than 230 million, making it one of the largest Muslim populations in the world. Due to its prominent number of Muslims, the proclivity toward fundamentalist concepts and ideology is strong, making the region vulnerable. Second, historically this region has been closely linked with the Muslim world, especially to the Middle East, South Asia and China. Such exposure makes this region open to radical ideas and approaches learned from the Middle East since 1960s. Furthermore, the past history, particularly the glorious decade of Islam in the region during the Malacca, Mataram and Pattani empires, may inspire some groups to look to the past for inspiration and hope of resurrecting past glory and challenging the present.

Third, the prolonged Islamic insurgency in several countries in this region provides opportunities for 
trans-national influences to penetrate the region. Fourth, the region is experiencing a rise of religious revivalism and fundamentalism that encourages these religious groups to reinterpret a reason for wars (Abuza, 2004). Finally some events including the success of the Islamic Revolution in Iran 1979, the conflict between Israel and Palestine, the US invasion of Iraq and Afghanistan, and the war on terror are viewed by these fundamentalists as a war on Islam, especially when the US is a strong supporter of Israel's invasion of Lebanon and Palestine (Sidel, 2007).

Despite the large Muslim population, history, ideas of revivalism and pan Islamism, Southeast Asia has porous borders that allow it to be a feasible transit and facilitation point for al-Qaeda to extend its influence and support. Al-Qaeda developed contacts with Islamic groups such as Abu Sayyaf Group (ASG) and Moro Islamic Liberation Front (MILF) in the Philippines, and Jemaah Islamiyah (JI) and Majlis Mujahiddin Indonesia (MMI) in Indonesia. Al-Qaeda is believed to have a close link to Kumpulan Militant Malaysia (KMM) in Malaysia as well (Acharya \& Acharya, 2007: 77). These groups and Al-Qaeda cooperate and share resources, transfer training, provide procurement of arms, endorse financial assistance, and teach terrorist methods of operation that raise their capacity to commit violent acts. They also seek to move forward the realization of their aim of the pan-Islamist objective: the establishment of Islamic states with Shariah law as the law of the land.

Before the September 11 attacks, Southeast Asia already faced danger in the region: the prospect of war on Spratly Islands; the power rivalry between China and the US seeking a balance of power in the region; on-going clashes between South and North Korea; China's claim on Taiwan; the separatist movement in Southern Thailand; and internal political strife in Indonesia. Moreover, the influence of Al-Qaeda in this region has been well-entrenched since the early 1990s. The operational preparation involved the September 11 attack was prepared with Nawaf Al-Hazmi and Khalid Al-Midhar, two of the September 11 hijackers from Bangkok and Kuala Lumpur (Acharya \& Acharya, 2007: 76)

However, Southeast Asia appears to be more of a transit support or facilitation point rather than an operational hub for Al-Qaeda's operational strategy. The Southeast Asian governments have had some success in discouraging the operational capabilities of well-known terrorist groups such as Jemaah Islamiyah (JI). This group is now fragmented and disorganized. Its main leaders, Abu Bakar Basyir and Omar Al-Faruq, are imprisoned; Detachment 88's top operative members, Nordin Mat Top and Dulmatin, are dead (Jakarta Post, April 26 2010). It would be premature to claim that the threat is no longer dangerous in Southeast Asia due to the absence of high profile terrorist figures and attacks in the region. Thus the presence of monolithic terrorism in Southeast Asia, particularly Malaysia and Indonesia, can be reassessed based on a few factors such as historical and cultural differences, governmental mechanisms to restrain terrorists' activities, detachment of terrorist organizations, sovereignty issues, and underlying poverty and underdevelopment issues.

\section{Competing Terms: Terrorism and Jihad}

\subsection{Terrorism}

The polemic to define terrorism evolves within the framework of means and ends. The dispute over competing meaning from the standpoint of media to academia is essentially endless. A few categories have been developed to define terrorism and to distinguish ways of carrying out violence within the society or outside the country, but the proper uses of such categories are still debatable.

Levels and mechanisms of radicalization are divided into three categories: individual, group and mass, each of which is composed of a variety of means to accomplish various ends. Personal victimization, political grievances, competition with state power, hate and martyrdom are some examples (McCauley and Moskalenko,2008: 418). Although these categories are able to identify forms of radicalization, reasons to commit violent acts have multiple and diverse pathways that can lead individuals and groups to such insanity with differing interests and motives. For example, Kimhi and Even (2006) argue that suicide terrorists in Palestinian cases are complex and involve multiple motives including religious methods for martyrdom, nationalist motives for independence of the Palestinian people, motives of revenge for personal or group victimization by Zionists, and motives of escape from personal problems. These motives could overlap one another and the degree of complexity as well as multiplicity proves that the pathway to terrorism is complicated.

Lutz and Lutz (2008) revitalized the definition of terrorism derived from Hoffman (2006), and Claridge (2006) that suggested that terrorism is the utilization of violence for political reasons that involve threat, target audience, and identifiable organizations. The act of violence is designed to create constant fear for target audiences that extend to non-immediate victims. Using violence for political reasons is similar to Schmid's (2004:197) outlines of other typical expressions used to describe terrorism such as indiscriminate bombings, hostage-taking, armed assaults, and hijacking. These acts are criminal offences of national and international laws. In other words, 
Schmid (2004) argues that political motives and criminal acts are tandem culprits that work as driving factors underpinning terrorist incidents.

Martin (2006) argues that groups that use violence in the name of faith are called fundamentalist groups and that they have become the predominant model for political violence in the modern world. He adds that the fundamentalist groups have increased in numbers, frequency, scale of violence, and global networks. Martin (2006) believes that fundamentalist groups are an important conduit responsible for turning individuals into terrorists. Fundamentalists propagate ideologies that bind individuals or groups together and that justify radical actions as necessary to gain success to resources and power. As a result, extremist groups become dangerous to others and a threat to society. Martin (2006) notes that fundamentalists facilitate acts of terror by providing information, logistical and financial assistance to groups of people that rationalize violence as necessary and required by belief to be praised in the "house of god." Intolerant reinterpretation of religious texts provides justification for violent acts as a way to correct the evildoers. These intolerant interpretations of religious texts are dangerous and ignorant.

Hoffan (2006) distinguishes left wing terrorists from fundamentalists that encompassing several comparative features as described as in Table 1. Despite the criteria for terrorism outlined above, Weinberg et al. (2004) view that the terms and concepts of terrorism are in dispute and suffer from several meanings due to appearances that are confused depending on form, place and circumstance. First, the word terrorism has been widely used to depict political unrest. However the phrase "freedom fighters" is used to engender people's inspiration for independence, giving a different meaning to terrorism (Ganor, 2004). Secondly, the word also suffers from a "stretching and travelling" problem when the act is carried out far away, making the meaning more benign at home. Third, the interpretation of acts of violence such as piracy, kidnapping, assassination, guerrilla warfare, and suicide bombing could be considered as terrorists acts or contested depending on motive of the perpetrators or the social standing of their victims (Weinberg, 2004:779).

Table 1. Differing interpretation between left-wing terrorists and fundamentalist

\begin{tabular}{|c|c|}
\hline LEFT-WING TERRORISTS: & FUNDAMENTALISTS: \\
\hline Secular; speaks for group & Religious; speak for God \\
\hline Target is selective, minimal collateral damage & Target is general, maximal collateral damage \\
\hline Often give advanced warning of bombings & Any advanced warning is of generalized threat \\
\hline No use of suicide bombing & Some use of suicide bombing \\
\hline Interested in constituency & Less interested in a constituency \\
\hline $\begin{array}{l}\text { Relies on bank robberies, kidnapping and } \\
\text { assassinations }\end{array}$ & Relies on bombings, armed attacks, and kidnapping \\
\hline $\begin{array}{l}\text { No interest in using chemical biological, radiological, } \\
\text { or nuclear attacks }\end{array}$ & $\begin{array}{l}\text { Interested in using chemical, biological, radiological or } \\
\text { nuclear attacks }\end{array}$ \\
\hline The attacks must further its goal & The attack may be warranted if it kills non-believers \\
\hline
\end{tabular}

Source: Copenhagen Consensus, 2008.

An uncertainty of magnitude results from differing connotations and interpretations on civilian fatalities and unwarranted damages that are most of the time overwhelming. In the Weinberg, et.al. study (2004: 781), the most frequent elements in acts of terrorism are violence, force, fear, threats, unpredictability, criminality, and victimization (target or public at large). They will be referred to later in this article for discussing terrorist networks in Malaysia and Indonesia. These terms are somewhat congruent with the legal definitions stipulated in both countries.

\subsection{Jihad}

The word Jihad stems from the Arabic word Jahada that means "to strive for a better way of life." When placed within the context of Islam, it encompasses all forms of striving, including constraining one's desire for all forms of hedonism, and aiming to make the word of God prevail. Yet this word has been erroneously defined as holy fighting in the cause of Allah or any effort to make Allah's word superior. The latter does not exist in Islam and only refers to the Holy War of the Crusaders (Ausop, 2003: 15).

Hussain Haqqani (2006:4) argues that there are eight cores of justification for militant jihad: the elimination of oppression and evil, the establishment of the supremacy of Islam, the humiliation of non-believers into paying 
taxes, the assistance of the weak and dispossessed, the revenge for the spilled blood of believers, the punishment for broken treaties, the defence of Muslim's land, and the securing of occupied Muslim territories. Any or all of these values could be used easily to justify violent acts.

The jihad concept in Southeast Asia in based on the Sayyid Qutb context of Jihad. The Gulf War, Western efforts to reorder the Middle East, support for Israel, focus on Iran, invasions in Iraq and the overthrow of Saddam Hussein bolstered Qutb's indictment of the West as the enemy of Islam. Jihad has been utilized to mobilize Muslims to resort to armed struggle, not for personal gain but for the good deeds of global Muslims. Western interventions to build democracy are refuted by most Muslims because their supreme ruler is Allah and not human. Humans are implementers that are subject to Allah's rule and will be accountable for any wrongdoings or any refusal to obey Allah's orders. Even when engaged in armed struggle, Islam does not condone terrorism, kidnapping, or hijacking, especially toward civilians. Islam prohibits Muslim soldiers from harming civilians, women, children, elderly persons and religious men such as priests and rabbis. Attacks on civilians are a violation of Islamic law and the offender is liable to punishment under the law. Furthermore violent attacks such as the one on the September 11 in the US are strongly unaccepted and condemned in Islam (Sukma, 2002: 14). Violent actions and the use of Jihad to legalize such acts are subjects of a radical interpretation guided by personal reasons and needs, and are thereby dangerous and misleading to society (Martinez, 2003: 35).

\section{Terrorist Networks in Malaysia and Indonesia}

Radicalization and terrorism are made possible by bringing individuals into small groups. Each group may take its own actions and may not necessarily be linked to a larger organization. McCauley and Moskalenko (2008: 427) argue that Al-Qaeda is an organization of groups that are disconnected from any larger centralized organization. The Bali suicide bombing was promulgated by a small self-organizing group involving siblings and kin of Jemaah Islamiyah members, rather than a cell embedded within Al-Qaeda to carry out that violence act. The Al-Maunah act of killing innocents was also detached from Al-Qaeda or Jemaah Islamiyah. Both incidents were carried out individually and the motives were based in personal hate, political grievance, religion, and group activism.

Before the September 11 attack, the spirit of Jihad had been embraced and displayed as helping the Muslim brothers and sisters on other continents. These home-grown radical fundamentalist groups sent their members to receive training and to participate in Jihad in Afghanistan during the USSR invasion. Here the Al-Qaeda influence has spread across the spectrum of Southeast Asia and extensive networks have been built for many years, since the early 1990s. For example Malaysian Yazid Sufaat was responsible for the Al Qaeda anthrax project in Afghanistan. He arranged lodging for the hijackers and used the cover of his wife's company in Kuala Lumpur to provide employment documents for Zacarias Moussaoui, the alleged $20^{\text {th }}$ hijacker for the September 11 attacks, to gain access to the United States (Archarya \& Acharya, 2007: 76-77).

Below are a few fundamentalist groups that are known to the government and being referred to by the media as terrorists.

\subsection{Fundamentalist Groups in Malaysia}

The Malaysian government defines terrorism based on its past experience in combating the Communist insurgency in 1948. Thus, Section 2 of the Internal Security Act (ISA) of 1960, revised in 1972, refers to a terrorist as "a person, who by use of any fire arm, explosive or ammunition, acts in any manner prejudicial to the public safety or the maintenance of public order or incites to violence or counsels disobedience to the law or to any lawful order." Although no bombings have occurred in Malaysia, it does not mean that Malaysia is free from threat. The netwar and network systems used by fundamentalist groups can strategically use Malaysia as their logistical or administrative hub.

Malaysia has no insurgent or separatist movement that is engaged in terrorist activities. The purported terrorist groups that exist in Malaysia are relatively small and inactive. Following the events of September 11, only then was Malaysia considered a hot spot for global terrorism because two hijackers that planned the attacks reportedly met in Kuala Lumpur (Acharya \& Acharya, 2007). A few fundamentalist groups in Malaysia are outlined below:

1) The Al-Mau'nah (Brotherhood of Inner Power)

Al- Mau'nah was established in Perak and caused a threat to national security when the it espoused the mix of Islam and martial arts to overthrow the government and aimed to establish an Islamic regime. Twenty-nine of its members walked into two army camps in Banding and Grik in Perak and drove off with an arsenal of 119 high-caliber modern weapons on July 2, 2000. It was believed that this group had supporters and followers in 
Brunei and Singapore. The government acted coercively, and the organization was dismantled, with all group members detained and imprisoned (Zabidi, 2003: 257-258).

\section{2) Kumpulan Militant Malaysia (KMM)}

This group is regarded as one of Malaysia's most active fundamentalist groups and they have close ties with groups in Indonesia, the Philippines, and Singapore. The KMM was formed in 1996 by a group of Mujahidin who fought in Afghanistan against the Russians. Following their return from Afghanistan, they elected Zainon Ismail as the group leader. Many of its members have been detained, but its network is still formidable with many members still at large. Ganesan (2002:151) argues that KMM works closely with Jemaah Islamiyah and its members and has been co-operatively involved with Al-Qaeda's ties to Nurjaman Riduan Isamuddin, also known as Hambali, to expand Al-Qaeda networks in this region.

3) Malaysian Jemaah Islamiyah (JI)

Malaysian JI was established in 1994. They work on the instruction of Sungkar, Abu Bakar Basyir, Hambali and Abu Jibrail. Members include Indonesian migrants, Malaysian students studying in Pakistan and professionals in varsities in Malaysia. Most members have undergone weapons and military training in Afghanistan and Pakistan (Balveer Singh, 2007: 80). Considering the JI in Malaysia works under the instruction of Sungkar, Abu Bakar Bashir, Hambali and Abu Jibrail - all are Indonesians, the influence of JI in Malaysia is less significant than the core JI in Indonesia. Other fundamentalist groups are on top of the lists and are given priority by the government of Malaysia.

\subsection{Fundamentalist Group in Indonesia}

The Indonesian government, through the Anti-Terror Bill or government In Lieu of Law issued on October 18, 2002 (PERPU No. 2, 2002/Art 6), defines terrorism as " the use of violence or threat to use violence either by individuals or collective groups that creates terror and fear on societies. Terrorist acts include confiscating other's independence of lives and properties, or creating massive destruction on vital and strategic projects, the environment, public property or international facilities." The religious groups in Indonesia are growing rapidly and are widespread. They mobilize their activities through Madrasah and mosques. There are hundreds of active groups in Indonesia at present. These groups outlined are believed to have a close links with Al-Qaeda.

1) Jemaah Islamiyah (JI)

Jemaah Islamiyah (JI) is an Islamist group that is deeply rooted in the Darul Islam movement of the 1950s. This historical piece possesses crucial repercussions for Muslim politics in Indonesia. Religion has numerous junctures in Indonesian history, including the long bloody battle against the Dutch colonials for independence, and it remains appealing with fearless warriors who fought against all odds facing the military brutality during the crackdown of Suharto's New Order regime in the late 1990s.

JI was formally established in 1993 after friction within Darul Islam resulted in the late Abdullah Sungkar leaving to form a splinter faction (Sulastri, 2010: 4). JI started out as an organization highly centralized and well structured. Its management was apparently top-down with a clear hierarchical order. The group also has its own charter, operational guidelines and strategic programs. The group manifesto is known as Pedoman Umum Perjuanga Al-Jamaah Al-Islamiyah (General Guide for the Struggle of Al-Jamaah Al-Islamiyah). However after the September 11 attacks and particularly after the first Bali bombings, suspected members of JI were relentlessly pursued in a massive crackdown across Southeast Asia. Then many observers believed that JI is merely a broken shell, especially after the capture or death of Riduan Isamuddin a.k.a Hambali, the bali Bombers, their accomplices and bomb expert Azahari Husin. (Sulastri, 2010: 4) .

2) Laskar Jihad

The beginnings of Laskar Jihad resulted from the conflict between Christians and Muslims in Maluku in 1999 that claimed thousands of lives. The group leader, Jafar Umar Thalib, was believed to be in the Mujahidin army, having fought in Afghanistan. Although Jafar Umar Thalib was believed to have connections with Al-Qaeda, he despised the September 11 attacks and dismissed Al-Qaeda as a different sect that was non-compliant with true Islamic practice. Members of Laskar Jihad were believed to have undergone military training at a camp near Munjul Village, Bogor, on a seven-hectare plot belonging to the Al-Irshad Foundation. Jafar Umar Thalib shares JI ideology in terms of defending Islam from enemies domestic and foreign. He does not support Al-Qaeda's ways of attacking the innocent but is active in helping oppressed Muslims in Ambon and Poso (Huang, 2002). 


\section{3) Laskar Jundullah (LJ)}

Laskar Jundullah means the Army of Allah. This group has been active in the Ambon and Poso conflicts as well as various other violent incidents in Sulawesi. LJ is closely associated with a group that supports JI, Komite Persiapan Penegakan Syariat Islam or the Preparatory Committee for Upholding Islamic Law, directed by Agus Dwikarna. He held a responsible acting role with Al-Qaeda leaders when they visited Indonesia. LJ is based in Makassar Sulawesi. Agus and another LJ key leader, Tamsil Linrung, were arrested in the Philippines for arms smuggling on March 2002. (Note 1)

4) The Medical Relief Charity.

Abuza (2010) argues that according to Indonesian intelligence, MERC is closely associated with the Saudi charity, the International Islamic Relief Organization, and has been alleged to channel funds to support JI. Even though MERC was established to assist Muslims caught in the sectarian conflicts in Maluku, it has been identified with JI leaders such as Abu Jibril , Agus Dwikarna, and Aris Munandar. In Indonesia, MERC has 12 branches and they are concentrated in areas involved in sectarian conflicts. Some observers have accused MERC of being a front for and supporter of JI.

\section{Malaysia and Indonesia: Differing Perceptions on Threat}

As a result of the US foreign policy that is viewed as hostile and oppressive to Muslims worldwide, Kuala Lumpur refuses to accept the link between terrorism and Islam, and views trans-national terrorism as the product of Western misdeeds against the global Muslim community. Similarly Jakarta continues to be hesitant to ban Islamic-based organizations on the basis that terrorism is a political issue that is closely tied to domestic political dynamics (Acharya \& Acharya, 2007: 81). Several factors result in differing perceptions of the threat to both Malaysia and Indonesia.

First, the link between Middle-Eastern and Malaysian-Indonesian practice of Islam is rather different based on history and culture. Both Malaysia and Indonesia favour a more moderate form Islam when compared to the Middle-East. Therefore it is unlikely that the similarities with regard to terrorism in Middle-East are significant. Unlike Middle-Eastern countries, both Malaysia and Indonesia are pluralistic, multi-religious, and multi-cultural societies (Acharya \& Acharya, 2007:86).

Second, the governmental mechanisms including bilateral relationships with the US, the renewal of defense agreements with Washington in 2005, acquisition and sharing of intelligence information, the joint anti-terrorism exercises between Indonesia and the US Navy Seals, and boarding ships and battling pirates open ways for extensive cooperation in the future (Acharya \& Acharya, 2007: 88). Although the US has not engaged in direct military combat, the cordial relations with Kuala Lumpur and Jakarta should be more about support for community development than direct military interference that could aggravate anti-American sentiments in both countries. People in this region are unhappy with Washington's narrowly conceived policy on the Middle-East that has long been labelled as anti-Muslim.

Third, the sensitivity to sovereign issues makes Indonesia and Malaysia disinclined to allow a more proactive involvement by the US. Both countries are protective against any outside interference in their waters. For example, the US proposal of the Regional Maritime Security Initiative (RMSI) to secure Southeast Asian waters was rejected. Malaysia believes that allowing such interference defeats its purpose against extremism and militancy. Kuala Lumpur propagates anti-terrorism through winning the hearts and minds of individuals. Indonesia is willing to accept help from the MI to drive out the US fleet if it comes to the Malacca Strait. (Note 2)

Fourth, under-development problems including poverty, fragile economic situations after the 1997 financial crisis, and political strife in both Indonesia and Malaysia are already troublesome. In fact, the tsunami in Acheh, frequent earthquakes in the areas surrounding Java and Sumatera, and the constant upheaval of the social civil rights movement in Malaysia have contributed to significant challenges for the government over the years. Furthermore, these countries have been heavily dependent on foreign trade, investment and tourism. The impact of a terrorist attack would potentially cripple these governments and tear apart the delicate multiracial and multi-religious social relationships.

Fifth, the perception of terrorism runs the risk of losing its vital radical meaning when an accused terrorist organization such as JI can hardly identify its members or unite them in means and goals. Different JI militants wage different jihad - some fight for a justifiable global battlefield while others view the conflict as local (Sulastri, 2010). Furthermore, there are repeated denials from alleged group members that JI exists at all. For instance, Abu Bakar Basyir has repeatedly rebuffed the existence of such an organization and has said that such a 
travesty is the invention to the enemies of Islam. Other accused JI members such as Sonhadi (Note 3) and Yusof (Note 4) do not view themselves as members of such groupings (Sulastri, 2010:6).

On the other hand, traditional and direct real time relationships are the foremost influencing factors when it comes to religious radicalization and extremist violence among JI members. Kinship and quasi-kinship networks tied together by blood, marriage, discipleship, and fraternity supersede personal impulses of the individual when it comes to carrying out a terrorist operation (Sulastri, 2010: 15). For example, in the October, 2002 Bali Bombings, Ali Ghufron a.k.a Mukhlas and Amrozi, a family of brothers pooling their strengths, were executed the November, 2008. In the JI marital pact involving ties between Mukhlas and Paridah Abas, a daughter from a family of jihadists based in Malaysia helped to expand the network in a secure way. In the marriage between Ari Aryani and Nordin Mat Top, the now dead terrorist fugitive suspected of being the mastermind behind the Jakarta twin hotel bombings, she is the daughter of Nordin Mat Top's associate. Bahrudin Latif, the disciple of a religious guru figure attached to various militant operations including Samudra a.k.a Abdul Aziz, the Bali bomber, deliberately chose to put the title imam to his name to showcase that he possessed legitimate religious authority to justify his violent actions. Finally, there is a fraternity where members of JI subscribe to be living by Islamic laws and principles in small groups of usroh. They reinforce solidarity among their members through a unique in-group language and appearance, usually consisting of baggy tops and matching pair of pants cropped above the ankles to visibly reveal their exclusive group identity (Sulastri, 2010:14).

\section{Malaysia and Indonesia: Counter Terrorism Approaches}

Malaysia's strategy to combat terrorism is two-fold: punitive measures and a non- security approach. The first prong emphasizes the use of law enforcement to counter terrorist activities. Detentions and arrests have been made against suspected JI members since December, 2001. Law enforcement has detained 99 members: 75 were in imprisoned, 7 were placed under restrictive orders, 8 were released unconditionally and 3 were deported. The JI Mantiqi Ulla in Peninsular Malaysia and mantiqi Thalith were dismantled in December, 2002 with key leaders such as Hambali, Dr Azhari Husin, Nordin Mat Top and Zulkifli Marzuki being forced to flee and seek refuge in neighbouring countries to evade capture.

Further action was taken when the government forcibly shut down the JI Luqmanul Hakime Islamic School in Ulu Tiram, Johor. In fact, the government requested that the Pakistani security agency put a halt to new Malaysian recruits to Madrasah in Pakistan as a way of preventing grooming sessions for new recruits and for leaders to succeed those who have been neutralized. (Note 5) In addition, the government enhances its national intelligence capabilities to thwart pre-planned terrorist operations. The Special Branch of the Royal Malaysia Police has intensified its counter-terrorism intelligence capability and information sharing with its counterparts at regional and international levels through training, education, consultation, and risk analysis provided through conferences and joint operations.

The second prong is a non-security measure that seeks to influence the hearts and minds of the people. Malaysia is committed to promoting a peaceful, moderate and democratic brand of Islam in the country. To that end, the government has suspended assistance to 500 Islamic religious schools allegedly misusing religion to promote anti-government sentiments and militant ideology. The government closely monitors students at religious schools and institutions at local and international higher institutions in Pakistan and India where virulent forms of Islam are being taught. As a counterbalance, the government has accelerated its efforts in ameliorating poverty in these areas. Poverty is viewed as the root of civil disobedience leading to terrorism. By spearheading economic development through the New Economic Transformation policy every effort is being made to remove economic imbalances among various ethnic groups (Shahbudin, 2005:9).

Meanwhile, the Indonesian government also applies direct and indirect approaches to counter terrorism. The direct approach refers to the government's ability to use coercive force freely to counter terrorism, primarily by intensifying and co-ordinating domestic intelligence operations. After the Bali bombing tragedy in 2001, President Megawati issued two Presidential Acts to intensify and co-ordinate domestic intelligence operations that could assist Indonesian authorities in finding and uncovering the terrorist networks. Presidential Act No 4/2002 authorizes the Minister for Political and Security Affairs to co-ordinate measures in combating terrorism. Similarly Presidential Act No 5/2002 gives the Head of Indonesian Intelligence the authority to gather and share information among various intelligence agencies such as Indonesia's State Intelligence Agency (BIN), the Indonesian Police Intelligence and Security Agency (BAINTELKAM POLRI), the Indonesian Armed Forces Strategic Agency (BAIS TNI), the $88^{\text {th }}$ Special Detachment, and others. This coordination is crucial because previously each agency operated independently (Sebastian, 2006:13; Muradi, 2009). 
Besides domestic intelligence operations and coordination, direct measures also include punitive action. Based on the anti-terrorism law (No.15/2003), more than $200 \mathrm{JI}$ members and members linked to Komiti Aksi Penaggulungan Kritis (KOMPAK) were captured (Schulze, 2002). The anti terror group called the $88^{\text {th }}$ Special Detachment police force was credited for their efficacy of tracking down the JI members during this intense rally to counter terrorism right after the Bali's bombing (Muradi, 2009). Detainees were put on trial and the sentences ranged from a minimum three years to life imprisonment or the death penalty depending on the type of crime committed.

Additionally the Indonesian government is working hand-in-hand with various other intelligence agencies such as the FBI (USA), Swedish Police Forces, Scotland Yard, Dutch Police, Japan National Police Agency, and ICPO-Interpol. In fact, under the scheme of the ASEAN Security Council (ASC) Indonesia has also established legal cooperation with other ASEAN countries. This cooperation has strengthened joint investigations among law enforcement officials, expediting resolution in criminal matters and extraditions (Dupont, 2005:45).

Indonesia's indirect strategy is a non-coercive action based on engagement. The Indonesian society and the police have long been at odds due to the police's militaristic operating procedures coupled with their arrogant attitude towards civilians. The government is aware of this enmity and tries to reduce it by encouraging civic participation. For instance, the Bali Community Policing Program involves non-government agencies (NGOs) that assist the police and the people in working together as a unified force. Local people are asked to help and give information to the police as a way of preventing any dubious activities (Jakarta Post, 23 March 2006).

Legal and intelligence measures are not enough to counter radical terrorist attacks. Conservative religious groups that operate at the grassroots level are a key component when their religious figures can be persuaded to cooperate. Because the public must be made aware that violent acts significantly damage the image of Islam, their practice must be totally rejected. The society must not allow itself to be hijacked by small radical groups (Sidel, 2007: 31). In order to strengthen the non-coercive strategy, the Indonesian government encourages the moderate Islamic groups such as PB NU, Muhammadiyah, and Jaringan Islam Liberal to collaborate with all the Islamic-based schools or pasentren, informing them that actions such as suicide bombing are foolish and misled. The program also includes clarification sessions on false perceptions about Jihad, martyrdom and suicide.

Even with a commitment to combat terrorism, it is difficult to know whether or not terrorist capability has weakened. It is important to note that although JI has lost several of its top operative members and its organization is disrupted, JI is not completely dismantled. The fundraising process is not affected by terrorist measures because the system of collecting money from the wealthy through zakat, infaq and sadoqah (part of Islamic religious duties) is done through mosques owned and managed by the Islamic groups. Direct donations to these Islamic groups are not easily controlled by the Indonesia authorities. Thus, organizational activities including enlisting manpower, preparing field operations, and training in arms use and technology can still be maintained (Abuza, 2002: 17).

\section{Terms and Approaches: Could They Be Assessed?}

Obviously, terms including terrorism, fundamentalism, and jihad are debateable and the debate could be endless. To simply say that terrorism and fundamentalism are one, is shallow and wrong. But to say if both are interchangeable and have the ability and capacity to carry a violent act that causes damages and catastrophe, yes they are possible. The term terrorism and fundamentalism both contribute to a differing range of devastation but such label cannot be placed easily to a religious group. A careful research must be carried out to avoid abusing the term to a real humanitarian group that works under the flag of religion, may it Islam, Christian, or other.

Furthermore, both Malaysia and Indonesia apply punitive measures and non security approaches to counter terrorism despite differing term used by the Indonesian government that are direct and indirect approaches. Although the programs to embrace moderate Islamic groups in the society seem encouraging in both Malaysia and Indonesia, it is difficult to ensure that both countries are free from the terrorist violent act or target. Government can set up a close monitoring system to all religious organizations, but such act can easily be manipulated or turn into a direct human rights violation of freedom (Nie, Y, 2009). In fact, pushing too hard against these religious groups could create hatred and could escalate into a more violent situation - a race riot.

Combating terrorism is a challenge to both Malaysia and Indonesia. Both have assessed the resources, culture and values, and capacities to counter terrorism within their means and ability. Both are firm not to allow a super power like the United States to get too far involve in their ways of combating terrorism. They support the US war on terror but refuse to accept a hierarchical relationship with the established power. Both countries adopt an approach that encourages the US to be the stabilizer for the region but decline to establish a formal military 
alliance with the United States. Thus, balancing the domestic needs, pressures and demands is vital for both Malaysia and Indonesia to maintain their political survival and peace in a multiracial state.

\section{Conclusion}

The issue of terrorism in Malaysia and Indonesia is similar to changing the current governmental system to Islamic Shariah Law. Terrorism is viewed as an internal political matter that must be handled deliberately, without interference from outsiders, particularly the US. Both governments show commitments to preventing terrorist activities from growing and causing harm to their nations and people. Although their level of determination is questionable when referring to their refusal to ban religious groups within their countries, this action is just and appropriate because the majority of their populations are Muslim. Such a ban would trigger mass rejection and dissatisfaction that would likely lead to social uprising against the government. At their core, religious organizations have been established for good causes and should be encouraged in those pursuits. They become problematic only when radical factions seek violent means to accomplish their ends. Ultimately Malaysia and Indonesia must cooperate closely with each other and the world to combat terrorism and pursue collaborative efforts such as training, exchanging ideas and information, and joint border operation consistently.

\section{References}

Abuza, Z. (2002). Tentacles of terror: Al-Qaeda's Southeast Asian Network. Contemporary Southeast Asia, 24(3), 427-465. http://dx.doi.org/10.1355/CS24-3A

Abuza, Z. (2004). Muslims, Politics, and violence in Indonesia: an emerging Jihadist- Islamist Nexus. Retrieved from http://www.nbr.org/publications/nbranalysis/pdf/vol15no3.pdf

Abuza, Z. (2005). Al-Qaeda Comes to Southeast Asia. In Paul J Smith (Ed.), Terrorism and Violence in Southeast Asia: Transnational Challenges to States and Regional Stability. USA: M.E Sharpe, Inc.

Abuza, Z. (2010). Indonesia counter terrorism. Retrieved from http://www.ocnus.net/artman2/publish/Defence_Arms_13/Indonesia_Counter Terrorism

Ahmad Fauzi Abdul Hamid. (2007, September 3). Islam and Violence in Malaysia, No. 123. S Rajaratnam School of International Studies, Singapore. Retrieved from www.rsis.edu.sg/publications/WorkingPapers/WP123.pdf

Ausop, A. Z. (2003). Islamic State of Indonesia: doctrines and movements, 1992-2002. Doctoral Dissertation, Indonesia: Universitas Islam Negeri Jakarta.

Azra, A. (2006). Islamic Radical Movement in Indonesia. The Jakarta Post, Indonesia. Retrieved from http://www.thejakartapost.com/Outlook2006/pol05b.asp

Dupont, A. (2005). Transnational violence in the Asia Pacific: an overview of current trends. In. Paul J Smith (Ed.), Terrorism and Violence in Southeast Asia: Transnational Challenges to States and Regional Stability. USA: Sharpe, Inc.

Ganor, B. (2003). Defining terrorism: Is One Man's Terrorist another Man's Freedom Fighter? Annual Editions: Violence and Terrorism. Guilford CT: Dushkin.

Ganor, B. (2005). The Counter Terrorism Puzzle: A Guide for Decision Maker. The Interdisciplinary Centre for Herzliya Project.

Gunaratna, R. (2006). Network, Structure and Threat Assessment. Seminar Introductory on Transnational Islamist Movements in Asia. Singapore: Institute of Defense and Strategy Study.

Haqqani, H. (n. d.). Understanding the History and Structure of Transnational Islamist Movements in Asia. A Report, an International Conference by International Centre for Political Violence and Terrorism. Retrieved from http://www.icpvtr.org

Hoffman, B. (2006). Inside Terrorism. USA: Colombia University Press.

Huang, R. (2002). Al-Qaeda in Southeast Asia: Evidence and Response. Centre for Defence Information. Retrieved from http://www.cdi.org/terrorism/sea.cfm

Kimhi, S., \& Even, S. (2006). The Palestinian Human Bombers. In Jeff Victoroff (Ed.), Tangled Roots: Social and Psychological Factors in the Genesis of Terrorism (pp. 308-323). Washington DC: IOS Press.

Lennon, A. T. J. (2003). The Battle for Hearts and Minds: Using Soft Power to Undermine Terrorist Networks. Cambridge: The MIT Press.

Lutz, J. M., \& Lutz, B. J. (2008). Global Terrorism (2nd ed.). London: Routledge. 
Martin, G. (2006). Understanding Terrorism, Challenges, Perspectives and Issues (2nd ed.). UK: Sage Publication.

Martinez, A. P. (2003). Deconstructing Jihad: Southeast Asian context. In. K. Ramakrishna, \& S. S. Than (Eds.), After Bali: The Threat of Terrorism in Southeast Asia. Singapore: Institute of Defence and Strategy Studies, Nanyang Technological University. http://dx.doi.org/10.1142/9789812561749_0003

McCauley, C., \& Moskalenko, S. (2008). Mechanisms of Political Radicalization: Pathways toward Terrorism. Terrorism and Political Violence, 20, 415-433. http://dx.doi.org/10.1080/09546550802073367

Muradi. (2009). The $88^{\text {th }}$ Densus AT: The Role and the Problem of Coordination on Counter Terrorism in Indonesia. Journal of Politics and Laws, 2(3).

Nie, Y. (2009). Protection of Human Rights in Countering Terrorism. Asian Social Science, 5(11), 33-38.

Osman, S. (2010). Jemaah Islamiyah: Off Kin and Kind. S. Rajaratnam School of International Studies, Singapore.

Schmid, A. P. (2004). Frameworks for Conceptualising Terrorism. Terrorism and Political Violence, 16(2), 197-221. http://dx.doi.org/10.1080/09546550490483134

Schulze, K. E. (2002, Spring). Laskar Jundullah and conflict in Ambon. The Brown Journal of World Affairs, $X(1)$.

Sidel, J. T. (2007). The Islamist Threat in Southeast Asia: A Reassessment. Washington: East-West Centre.

Singh, B. (2007). Tha Talivanization of Southeast Asia: Losing the war on terror to Islamist extremism. USA: Greenwood Publishing Group, Inc.

Sukma, R. (2002). Indonesia's Islam and September 11: Reactions and Prospects. In Andrew Tan, \& Kumar Ramakrishana (Eds.), The New Terrorism: Anatomy, Trends, and Counterstrategies. London: Times Media Private Ltd.

Weinberg, L., Pedahzur, A., \& Hirsch-Hoefler, S. (2004). The Challenges of Conceptualizing Terrorism. Terrorism and Political Violence, 16(4), 777-794. http://dx.doi.org/10.1080/095465590899768

\section{Notes}

Note 1. Baradan Kuppusamy. Can Christians Say Allah? In Malaysia, Muslims Say No” Time, 8 January 2010.

Note 2. Militant Group Says Ready to Help "Drive Out" US Fleet From Malacca Strait. BBC News, May 21, 2004.

Note 3. Sonhadi is the current leader of the Basyir led JAT in East Java who had served time for helping the late terrorist fugitive Nordin Mat Top when the latter was on the run. Sonhadi keeps reiterating that he helped Nordin Mat Top on the basis of a duty of Muslim brother to help a fellow Muslim who had a run-in with the law.

Note 4. Yusof is a militant who once trained under Nasir Abas in Mindanao and was later arrested in Semarang for illegal arms, and he did not find himself as a militant for JI. He claimed that he is only loyal to the cause and to his comrades in the battlefield in Mindanao.

Note 5. International Crisis Group Report, 2010. http://www.crisisgroup.org/homr.index.cfm 